\title{
RANCANG BANGUN REGENERATIVE SHOCK ABSORBER (RSA) PADA KENDARAAN RODA EMPAT
}

\author{
Novian Fajar Satria ${ }^{1}$, Didik Setyo Purnomo ${ }^{2}$ \\ ${ }^{1,2}$ Mekatronika, Politeknik Elektronika Negeri Surabaya, \\ Jl. Raya ITS, Kampus PENS, Sukolilo, Surabaya, 60111 \\ e-mail: ${ }^{1}$ ovinmeka@pens.ac.id, ${ }^{2}$ didiksp@pens.ac.id
}

\begin{abstract}
four-wheel vehicles have the energy to be dissipated, one containing the vehiclesuspension system caused by excitation forces from outside. Research and development of Regenerative ShockAbsorber (RSA) has been done by some previous researchers still use the concept ofsingle input and single output. This research will be developed by RSA which use this type ofhydraulic suspension with 2 inputs and 1 output. The first step in this research is to design Regenerative Shock Absorber (RSA) 2 input 1 output. Thensimulation using software FluidSim to determine the design of RSA 2 inputs 1output to the hydraulic motor works well. The next step is to create a prototypeRSA and tested through experiments on vehicles. The result that the hydraulic circuit RSA can align the rotation of the hydraulic motor. Through testing experimentally obtained RSA electricalenergy generated when crossing rough roads (paving) at a speed of $30 \mathrm{~km} / \mathrm{h}$ is 1,32 Watt and 0,06 Watt when burdened battery. And when crossingbumps with a height of $4 \mathrm{~cm}$ vehicle speed of $10 \mathrm{~km} / \mathrm{h}$ obtained at 2:47 RSAenergy generation in the Watt without battery overload and 0:15 Watt when burdenedby a battery.
\end{abstract}

Key words : Regenerative Shock Absorber (RSA), Electrical Energy, Hydraulic Motor.

\section{ABSTRAK}

Kendaraan roda 4 memiliki energi terdisipasi, salah satunya terdapat pada sistem suspensi kendaraan yang diakibatkan oleh gaya eksitasi dari luar. Penelitian dan pengembangan Regenerative Shock Absorber (RSA) yang telah dilakukan oleh beberapa peneliti terdahulu masih menggunakan metodesingle input dan single output generator dimana didapatkan keluaran berupa energi bangkitan yang masih sedikit. Pada penelitian ini akan dikembangkan RSA yang menggunakan jenis suspensi hidrolik dengan metode 2 input dan 1 output. Langkah pertama yang dilakukan pada penelitian ini adalah membuat rancangan Regenerative Shock Absorber(RSA) 2 input 1 output. Kemudian dilakukan simulasi menggunakan software FluidSim untuk mengetahui rancangan dari RSA 2 input 1 output terhadap motor hidrolik bekerja dengan baik. Langkah selanjutnya adalah membuat prototype RSA dan diuji coba melalui eksperimen pada kendaraan. Dari penelitian didapatkan hasil bahwa rangkaian hidrolik RSA dapat menyearahkan putaran dari motor hidrolik. Melalui pengujian secara eksperimen, didapatkan energi listrik yang dihasilkan RSA pada saat melintasi jalan kasar (paving) pada kecepatan $30 \mathrm{Km} / \mathrm{h}$ adalah 1.32 Watt tanpa dibebani battery, dan 0.06 Watt ketika dibebani battery. Ketika melintasi polisi tidur dengan ketinggian $4 \mathrm{Cm}$ kecepatan kendaraan $10 \mathrm{Km} / \mathrm{h}$ didapatkan energi bangkitan RSA sebesar 2.47 Watt tanpa di bebani battery dan 0.15 Watt ketika dibebani oleh baterai.

Kata kunci : Regenerative Shock Absorber (RSA), Energi Listrik, Motor Hidrolik

\section{PENDAHULUAN}

Kebutuhan akan sumber energi di masa depan menjadi salah satu topik pembahasan yang sangat gencar diperbincangkan oleh para pakar peneliti di seluruh dunia. Berbagai aspek dalam kehidupan ini tengah diteliti untuk mencari sumber energi alternatif yang dapat dihasilkan dalam memenuhi kebutuhan energi di masa depan. Salah satunya dalam bidang otomotif pada sistem suspensi kendaraan. Sistem suspensi pada kendaraan dirancang dan digunakan untuk menyerap kejutan atau hentakan dari permukaan jalan yang dilewati kendaraan sehingga menghasilkan 
kenyamanan dalam berkendara ketika melewati jalanan yang bergelombang. Sistem suspensi ini terletak diantara bodi kendaraan dengan roda-roda. Komponen pada sistem suspensi yang bertugas untuk meredam osilasi (gerakan naik turun) pegas saat menerima kejutan atau hentakan dari profil jalan yang bergelombang dinamakan shock absorber. Majanasastra (2014) memaparkan bahwa shock absorber adalah satu bagian yang terpenting dari sistem suspensi yang bekerja untuk meredam atau menetralisir dengan cepat vibration (getaran) spring (pegas) pada kendaraan roda empat yang terjadi akibat kondisi jalan yang tidak beraturan serta mengendalikan kestabilan dan kenyamanan dalam berkendaraan. Dalam pengembangannya shock absorber juga memperhitungkan dua aspek, seperti dijelaskan oleh [6], pengembangan suspensi regeneratif harus memperhatikan dua aspek, yaitu aspek dari kemampuan sistem meregeneratif energi dan kenyamanan yang diberikan.

Banyaknya energi yang terdisipasi pada kendaraan, membuat penelitian ke arah suspensi regeneratif semakin berkembang. Qiu dkk (2013) mengklasifikasikan suspensi regeneratif menjadi dua tipe berdasarkan prinsip kerjanya, yaitu suspensi regeneratif mekanik dan suspensi regeneratif elektromagnetik. Suspensi regeneratif elektromagnetik mentransformasi shock energy menjadi energi listrik yang dapat disimpan dan digunakan ulang. Pada penelitiannya, Syuhri (2015) menggunakan tipe suspensi regeneratif elektromagnetik dan mendapatkan energi bangkitan dari sistem HRSA yang telah dibuatnya lalu diaplikasikan pada quarter car model dan didapakan arus maksimal sebesar 0,8 A dan daya bangkitan maksimal sebesar $10 \mathrm{~W}$. Dari hasil penelitian Berdasarkan analisa komprehensif Lin dan Xuexun (2010), tipe hydraulic electromagnetic suspension atau lebih dikenal dengan nama hydraulic regenerative shock absorber (HRSA), memiliki keuntungan baik dari sisi fleksibilitas sistem hidrolik dan dari sisi regenerasi energinya. Struktur yang sederhana dan tidak membutuhkan banyak komponen menjadikannya mudah untuk diaplikasikan.

Rumusan permasalahan yang diambil dari penelitian ini adalah bagaimana disain dari sistem hydro-magnetoelectric regenerative shock absorber (RSA) dengan 2 input 1 output serta bagaimana karakteristik energi bangkitan dari prototype RSA dengan 2 input 1 output pada kendaraan roda empat. Dari permasalahan tersebut akan didapatkan tujuan dari penelitian ini yaitu mendesain rancangan hydromagneto-electric regenerative shock absorber (RSA) dengan 2 input 1 output serta membuat prototype dan melakukan pengujian karakteristik prototype hydro-magneto-electric regenerative shock absorber (RSA) dengan 2 input 1 output melalui eksperimen pada kendaraan roda empat.

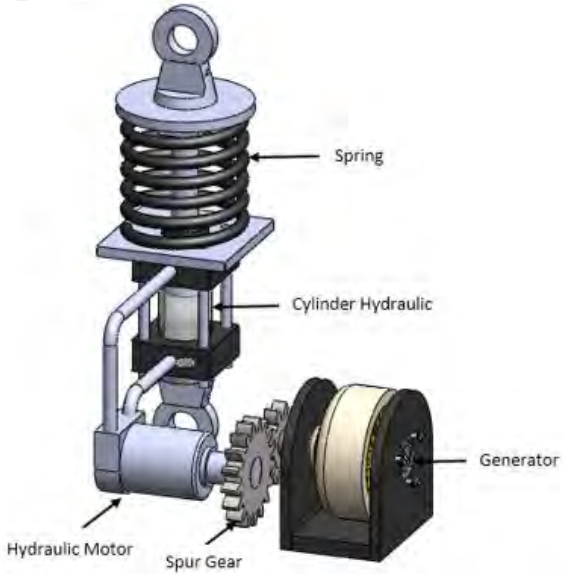

Gambar 1. Konstruksi hidraulik motor regenerative shock absorber

Penelitian akan RSA juga dilakukan oleh Anuar (2014) mahasiswa Institut Teknologi Sepuluh Nopember (ITS) dengan merancang hydraulic motor regenerative shock absorber (HMRSA). Pada Gambar 1.1 terlihat bahwa komponen hydraulic motor regenerative 
shock absorber ini terdiri dari spring, cylinder hydraulic, hydraulic motor, spur gear, dan generator. Prinsip kerja dari alat ini adalah memanfaatkan energi kinetik pada gerakan suspensi kendaraan. Energi tersebut ditransfer ke sebuah motor hidrolik. Gaya yang ditransfer dari motor hidrolik kemudian ditransmisikan oleh susunan roda gigi yang berfungsi untuk meningkatkan putaran generator. Putaran generator tersebut akan menghasilkan energi bangkitan. Daya listrik yang dihasilkan HMRSA ini berkisar antara 0.024 watt sampai 1.1078 watt dengan model $1 / 4$ kendaraan.

Syuhri(2015) juga mengembangkan RSA untuk mendapatkan energi bangkitan yang diambil dari sistem suspensi pada kendaraan. Pada penelitiannya, Syuhri fokus dalam mengetahui karakteristik gaya redam dan juga energi bangkitan yang dihasilkan melalui alat yang dibuatnya. Pada Gambar 1.2 terlihat skema dari HMRSA yang dikembangkannya. Pengembangan yang dilakukan pada HMRSA ini adalah dengan perubahan rangkaian hidrolik dan penambahan mekanisme check valves agar putaran motor hidrolik menjadi searah sehingga mengurangi losses akibat putaran yang tidak searah. Pengembangan lain adalah mengganti generator yang digunakan. Generator yang digunakan pada penelitian ini adalah generator PMG100. Motor hidrolik yang digunakan adalah tipe BMM 8. Perbandingan roda gigi adalah 2.65, dengan diameter roda gigi pada motor hidrolik $115.6 \mathrm{~mm}$ dan roda gigi pada generator $43.6 \mathrm{~mm}$.

Studi pengaruh perubahan tekanan accumulator terhadap karakteristik redaman dan energi listrik bangkitan pada Hydraulic Regenerative Shock Absorber (HRSA) juga dianalisa pada penelitian ini. Tekanan accumulator hanya mempengaruhi redaman mekanik, tetapi energi listrik bangkitan turun, dan semakin besar tekanan accumulator akan semakin besar pula gaya redam yang dihasilkan. efisiensi tertinggi ketika tidak menggunakan accumulator. Hal ini terjadi karena semakin tinggi kecepatan, redaman mekanik seperti inersia, redaman akibat luas penampang silinder dengan check valve, dan head loss pada sistem perpipaan juga semakin meningkat. Sehingga daya listrik yang dihasilkan dengan daya mekanik semakin menurun. Dalam pengujiannya, dapat diketahui energi bangkitan HMRSA pada frekuensi $1.3 \mathrm{~Hz}, 1.5 \mathrm{~Hz}$, dan 1.7 Hz berturut-turut adalah 1.017 W, 1.745 W, dan $2.332 \mathrm{~W}$.

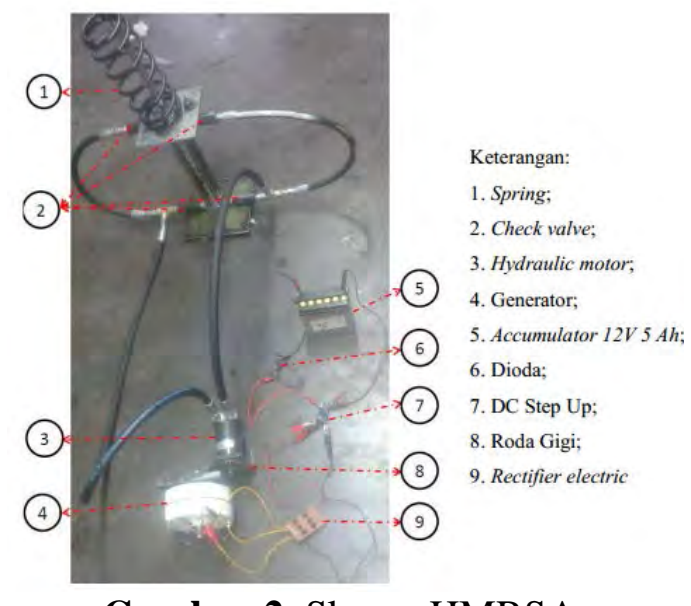

Gambar 2. Skema HMRSA

\section{METODE PENELITIAN}

Disain RSA dirancang berdasarkan tema yang diangkat pada penelitian ini yaitu dengan menggunakan 2 input dan 1 output, dimana akan digunakan 2 silinder hidrolik sebagai input yang kemudian dihubungkan pada 1 motor hidrolik sebagai output. Generator akan digerakkan oleh motor hidrolik menggunakan gear dengan perbandingan rasio gear yang akan ditentukan nantinya sehingga putaran di generator akan lebih cepat dari pada putaran di motor hidrolik. Rangkaian hidrolik dari 2 silinder hidrolik yang digunakan akan saling berhubungan melalui selang hidrolik yang khusus untuk bisa mengalirkan fluida (oli) dari 
pergerakan naik dan turun piston pada silinder hidrolik tersebut yang menyebabkan perputaran aliran fluida (oli). Motor hidrolik akan digerakkan melalui putaran aliran fluida yang diakibatkan oleh pergerakan silinder hidrolik akibat gaya eksitasi dari luar.

Untuk dapat menyearahkan putaran dari motor hidrolik perlu dibuat jalur skema dari rangkain hidrolik tersebut dan dalam hal ini menggunakan komponen hidrolik yang dikenal dengan nama check valve atau katub searah. Fungsi dari check valve ini supaya aliran dapat terhenti dan mengikuti jalur aliran rangkaian yang sudah ditentukan dan dirancang. Untuk menghubungkan 2 selang dari 2 silinder hidrolik tersebut digunakan Tee-Junction atau dikenal dengan sambungan T hidrolik. Gambar 3 menunjukkan perancangan disain dari RSA menggunakan 2 input dan 1 output.

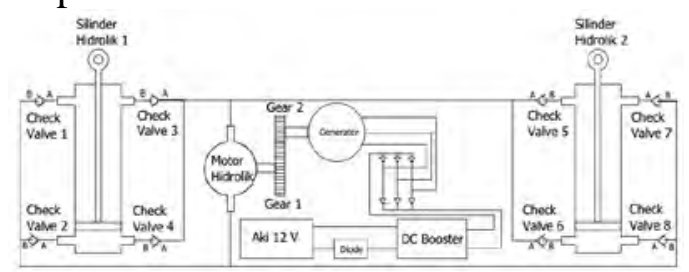

Gambar 3. Perancangan Disain RSA

Dasar perencanaan dari perancangan disain RSA adalah dari tujuan sistem yang ingin dibuat yaitu 2 input 1 output dengan mengacu pada penelitian sebelumnya yang dilakukan oleh Syuhri(2015). Pada penelitiannya Syuhri juga menggunakan prinsip kerja hidrolik untuk menggerakkan motor hidrolik yang dihubungkan dengan generator. Pengembangan yang dilakukan pada penelitian ini adalah penambahan satu silinder hidrolik pada sistem dimana penelitian yang sebelumnya menggunakan satu buah silinder, pada penelitian kali ini digunakan 2 silinder hidrolik. Selain itu juga ditambahan komponen check valve juga tee-junction untuk tetap membuat putaran dari motor hidrolik menjadi satu arah.Berikut ini adalah ilustrasi proses aliran fluida saat piston bergerak ke bawah (kompresi) yang ditunjukkan oleh Gambar 4.

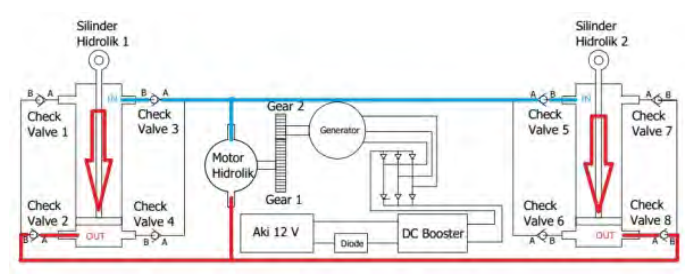

Gambar 4. Ilustrasi pergerakan fluida saat kompresi

Berikut pada Gambar 5 ditunjukkan alur dari pergerakan fluida ketika piston bergerak ke atas ekspansi.

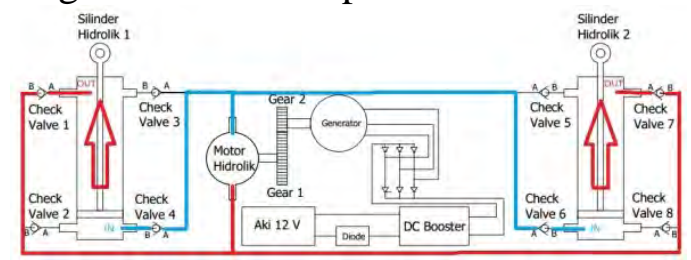

Gambar 5. Ilustrasi pergerakan fluida saat ekspansi

Dalam proses pembuatan desain prototype RSA menggunakan software gambar Autodesk Inventor Profesional 2016. Setiap komponen yang sudah dirancang sebelumnya pada perancangan RSA digambar secara 3D, sehingga nantinya dapat membantu untuk menggambarkan hasil jadinya. Setelah melalui proses desain konstruksi RSA, maka akan masuk pada tahap pembuatannya atau manufakturingnya. Kemudian setelah selesai diuat semua komponen akan dirakit sesuai dengan perancangan desain RSA yang telah dibuat. Kemudian dilakukan uji coba dengan mengisi selang dan silinder hidrolik dengan oli yang digunakan, apakah terdapat kebocoran atau tidak.

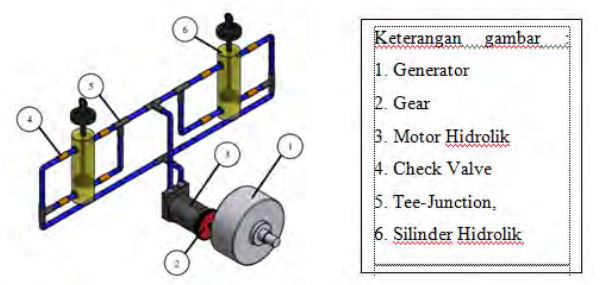

Gambar 6. Desain konstruksi RSA

Pada tahap pengujian energi bangkitan RSA ini, maka prototype RSA yang 
telah dibuat akan diinstal/dipasang pada kendaraan roda 4 yaitu Daihatsu Grand Max Pick Up. Kemudian akan dilakukan pengujian/eksperimen pengambilan data dengan langsung menguji prototype RSA ketika kendaraan berjalan pada medan jalan baik yang lurus maupun yang ada gundukan / polisi tidur pada jalan tersebut, sehingga akan keluar data berupa besaranya energi bangkitan yang dihasilkan oleh prototype RSA. Berikut pada Gambar 7 adalah skema pengujian dari energi bangkitan RSA pada kendaraan. Untuk mengetahui energi bangkitan yang dihasilkan oleh RSA digunakan alat yaitu Osciloscope dan juga Avometer. Fungsi dari oscilloscope adalah untuk mengetahui besarnya tegangan yang dihasilkan, sedangkan avometer berfungsi untuk mengetahui nilai dari arus yang dihasilkan. Rumus untuk mencari daya (watt) adalah

$\mathrm{P}=\mathrm{V} \times \mathrm{I}$

dengan $\mathrm{V}$ adalah tegangan yang dihasilkan RSA, dan i adalah arus yang dihasilkan oleh RSA.

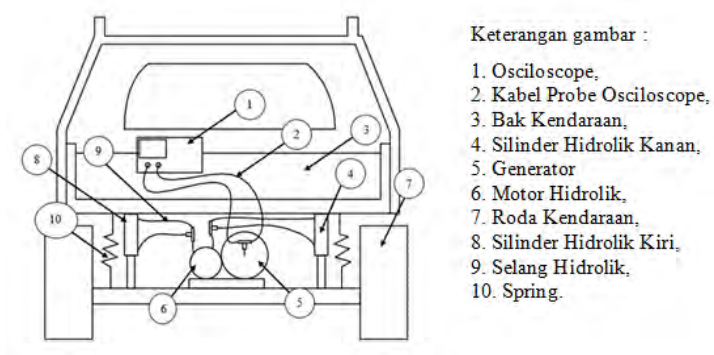

Gambar 7. Skema Pengujian RSA

\section{HASIL dan PEMBAHASAN}

Pemasangan RSA pada kendaraan seperti pada Gambar 8 dimana RSA diletakkan di bagian bawah bak kendaraan pick-up bagian belakang. Pada Gambar 9 adalah alat dan komponen yang telah dirangkai untuk mendapatkan data pengujian dari energi listrik yang dihasilkan dari sistem RSA.

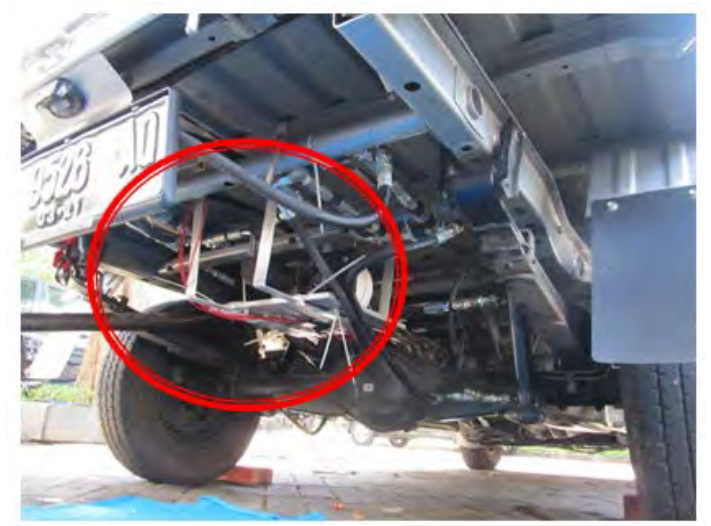

Gambar 8. RSA pada kendaraan

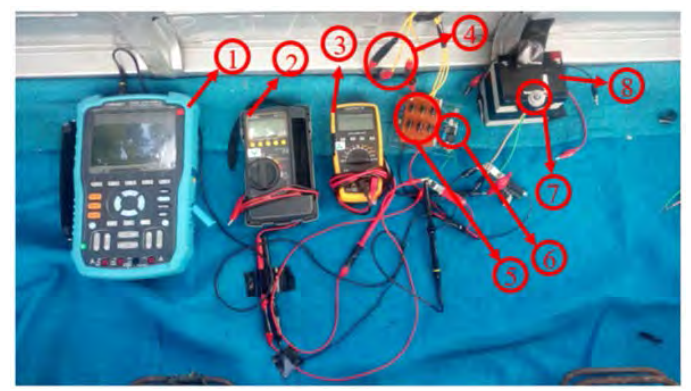

Gambar 9. Rangkaian pengambilan data RSA

Keterangan Gambar : 1. Osciloscpe, 2. Multimeter digital (V), 3. Multimeter digital (A), 4. Output dari generator AC, 5. Rectifier, 6. DC Step Up, 7. Lampu, 8. Battery (aki).

Pengujian pada profil jalan kasar (paving) dilakukan dengan kondisi mobil berjalan lurus maju ke depan. Dalam pengujian ini, pengambilan data dilakukan pada kondisi ketika sistem RSA tanpa dibebani oleh battery (aki) dan ketika sistem RSA dibebani oleh battery (aki). Berikut ini adalah hasil dari pengujian dan pengambilan data dari sistem RSA. Pada Gambar 1.10 adalah grafik dari pengujian sistem RSA tanpa dibebani oleh batteray (aki) menggunakan osciloscope. Pada oscilloscope tersebut diatur nilai dari skala Volt/Div adalah 5.00 Volt, sedangkan untuk Time/Div adalah 1.00 s. Berdasarkan hasil dari pengujian eksperimen tersebut, didapatkan nilai dari tegangan tertinggi yaitu Vp-p adalah 13 Volt. Untuk mengetahui nilai tegangan rata-rata digunakan persamaan Vrms sebagai berikut : 
Vrms $=(V p-p) /(2 \sqrt{ } 2)$

Dengan menggunakan persamaan (2) didapatkan nilai dari tegangan rata-rata ketika melewati jalan kasar (paving) adalah 13 Volt $/ 2 \sqrt{ } 2=4.61$ Volt. Pada Gambar 10 adalah nilai dari arus yang dapat dihasilkan oleh sistem RSA. Nilai arus tersebut didapatkan dalam video rekaman ketika pengujian denga nilai arus sebesar $287.9 \mathrm{~mA}$. Dengan diketahuinya nilai tegangan dan arus yang dihasilkan oleh sistem RSA ketika pengujian, didapatkan besar daya yang dapat dihasilkan dengan persamaan $\mathrm{P}=$ $\mathrm{V} \times \mathrm{I}$.

Tegangan yang dihasilkan adalah 4.61 Volt, dan arus yang dihasilkan adalah $0.287 \mathrm{~A}$, sehingga daya yang dihasilkan adalah 1.32 Watt.

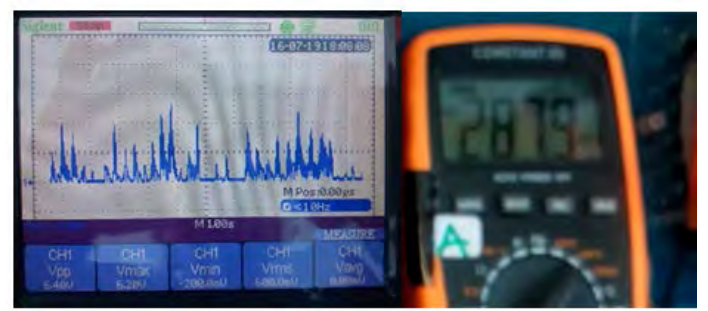

Gambar 10. Tegangan dan arus yang dihasilkan tanpa pembebanan aki

Pengujian dan pengambilan data yang selanjutnya adalah rangkaian elektronik diberi beban battery (aki). Dalam hal ini adalah energi listrik yang dihasilkan oleh RSA diteruskan untuk melakukan pengisian ke dalam battery (aki). Battery (aki) yang digunakan memiliki spesifikasi tegangan 12 Volt dan 5 A. Kondisi battery (aki) pada kapasitas $50 \%$. Untuk pengaturan skala dari Volt/Div dan juga Time/Div masih sama seperti pada pengaturan untuk pengujian tanpa dibebani oleh battery yaitu 5.00 Volt untuk Volt/Div dan 1.00 s untuk Time/Div.

Pengujian pada polisi tidur dilakukan dengan kondisi mobil berjalan lurus maju ke depan kemudian mendekati polsisi tidur dilakukan pengurangan kecepatan. Dalam pengujian ini, pengambilan data dilakukan pada kondisi ketika sistem RSA tanpa dibebani oleh battery (aki) dan ketika sistem RSA dibebani oleh battery (aki). Berikut ini adalah hasil dari pengujian dan pengambilan data dari sistem RSA. Ketinggian dari polisi tidur adalah $4 \mathrm{~cm}$ seperti yang terlihat pada Gambar 11 .

Tabel 1. Pengambilan data eksperimen RSA di jalan kasar

\begin{tabular}{|l|c|c|c|c|c|}
\hline \multicolumn{1}{|c|}{ Kondisi } & $\begin{array}{c}\mathrm{V} \\
(\mathrm{km} / \mathrm{h})\end{array}$ & $\begin{array}{c}\text { Vp-p } \\
(\text { Volt })\end{array}$ & $\begin{array}{c}\text { Vms } \\
(\text { Volt })\end{array}$ & $\begin{array}{c}\mathrm{I} \\
(\mathrm{mA})\end{array}$ & $\begin{array}{c}\text { P } \\
(\text { Watt })\end{array}$ \\
\hline $\begin{array}{l}\text { Tarpa } \\
\text { beban aki }\end{array}$ & 30 & 13 & 4.61 & 287.9 & 1.32 \\
\hline $\begin{array}{l}\text { Dengan } \\
\text { beban aki }\end{array}$ & 30 & 5 & 1.77 & 34.43 & 0.06 \\
\hline
\end{tabular}

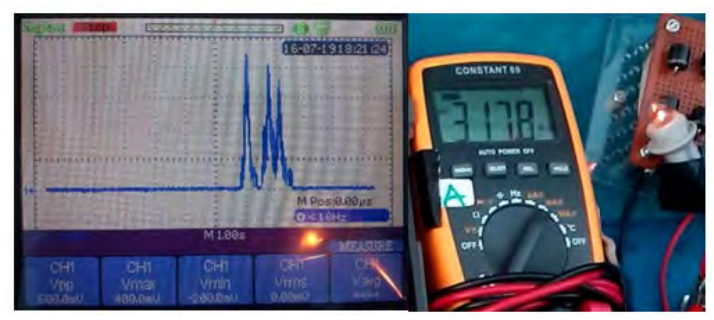

Gambar 11. Tegangan dan arus yang dihasilkan tanpa pembebanan aki

Pada grafik Gambar 11 terlihat nilai tegangan Vp-p mencapai nilai 22 Volt. Dengan menggunakan persamaan (2) diketahui nilai Vrms dari tegangan yang dihasilkan adalah 7.8 Volt. Sedangkan arus yang dihasilkan pada eksperimen kondisi ini terlihat pada Gambar 11 yaitu sebesar $317.8 \mathrm{~mA}$. Dengan demikian dapat diketahui daya yang dihasilkan oleh RSA pada saat melintasi polisi tidur dengan ketinggian $4 \mathrm{~cm}$ tanpa dibebani oleh baterai adalah sebesar 2.47 Watt. Besarnya daya yang dihasilkan berbanding lurus dengan tegangan dan arus yang dihasilkan, semakin besar tegangan dan juga arus yang dihasilkan maka daya yang dihasilkan akan semakin besar. Dan besarnya nilai tegangan dan arus yang didapatkan bergantung dari pergerakan silinder hidrolik ketika melakukan ekspansi maupun kompresi.

Pengujian yang terakhir adalah dengan diberikannya pembebanan baterai (aki) ketika kendaraan melintasi polisi tidur. Dengan kata lain ketika sistem RSA menghasilkan energi listrik akan digunakan untuk mengisi battery 
tersebut. Hasil pengambilan data dari ekpserimen dari kondisi tersebut respon tegangan menunjukkan angka 5 Volt untuk nilai Vp-p. Dengan persamaan (1) diketahui nilai dari Vrms yaitu 1.77 Volt. Untuk arus yang dihasilkan adalah sebesar $90 \mathrm{~mA}$. Daya yang dihasilkan sebesar 0.15 Watt. Penurunan nilai tegangan dan arus juga terjadi pada kondisi ini dibandingkan dengan kondisi tanpa diberikan beban berupa battery (aki). Terjadinya penurunan nilai tegangan dan arus ketika diberikan pembebanan battery dikarenakan daya yang dihasilkan oleh sistem RSA tidak mencukupi kebutuhan dari battery ketika pengisian.

Tabel 2. Pengambilan data eksperimen RSA di polisi tidur

\begin{tabular}{|l|c|c|c|c|c|}
\hline Kondisi & $\begin{array}{c}\mathrm{V} \\
(\mathrm{km} / \mathrm{h})\end{array}$ & $\begin{array}{c}\text { Vp-p } \\
\text { (Volt) }\end{array}$ & $\begin{array}{c}\text { Vms } \\
\text { (Volt) }\end{array}$ & $\begin{array}{c}\mathrm{I} \\
(\mathrm{mA})\end{array}$ & $\begin{array}{c}\mathrm{P} \\
\text { (Watt) }\end{array}$ \\
\hline $\begin{array}{l}\text { Tarpa } \\
\text { beban aki }\end{array}$ & 10 & 22 & 7.8 & 317.8 & 2.47 \\
\hline $\begin{array}{l}\text { Dengan } \\
\text { beban aki }\end{array}$ & 10 & 5 & 1.77 & 90.9 & 0.15 \\
\hline
\end{tabular}

\section{KESIMPULAN}

Berdasarkan hasil dari pengujian eksperimen dari sistem RSA dengan 2 input 1 output didapatkan kesimpulan bahwa rancangan desain dari RSA dengan 2 input 1 output dapat berjalan dengan baik ditandai dari putaran motor hidrolik menjadi satu arah ketika kondisi ekspansi maupun kompresi. Pembuatan prototype RSA telah sesuai dengan rancangan dari rangkaian hidrolik RSA dan dapat diinstal pada kendaraan roda 4, juga didapatkan hasil dari energi bangkitan dari sistem RSA melalui uji eksperimen yang telah dilakukan. Hasil energi bangkitan kecil dikarenakan proses pengisian oli yang tidak bisa maksimal untuk memenuhi seluruh rangkaian selang hidrolik. Perlu diperhatikan terkait proses memasukkan oli ke dalam rangkaian hidrolik dan silinder hidrolik sebagai shock absorbernya, karena sangat berpengaruh terhadap volume oli yang mengisi seluruh rangkaian hidrolik.

\section{DAFTAR PUSTAKA}

[1] Anuar, Kaspul, dan Guntur, Harus L, 2014, Karakteristik Gaya Redaman dan Energi Bangkitan dari Regenerative Shock Absorber dengan Motor Hidrolik, Tesis, Master, Institut Teknologi Sepuluh Nopember, Surabaya.

[2] Guntur, Harus L., 2016, ”Analysis of The Influence of Hydraulic Cylinder Diameter to The Total Damping Force and The Generated Electricity of Regenerative Shock Absorber", ARPN Journal of Engineering and Applied Sciences, Vol. 11, No. 2, hal. 873-878.

[3] Lin, Xu., Yang, Bo., Xuexun, Guo., 2010, "Simulation and Performance Evaluation of Hydraulic Transmission Elctromagnetic Energy-Regenerative Active Suspension”, Second WRI Global Congress Intelligent Systems, Intelligent System, hal. 58-61, Wuhan.

[4] Majanasastra, R. Bagus Suyasa. 2014. Analisis Shock Absorber Roda Depan Kendaraan Roda Empat Jenis Suzuki Carry 1000. Jurnal Ilmiah Teknik Mesin, Vol. 2, No. 1, hal. 1-16.

[5] Qiu, Zhang Jin., Zhao, Peng Zhi., Lei Zhang, dan Yu Zhang, 2013, "A Review on Energy Regenerative Suspension Systems for Vehicle”, Proceedings of the World Congress on Engineering, hal 1889-1892. London. 
Novian Fajar Satria dan Didik Setyo Purnomo, Rancang Bangun Regenerative .....

[6] Syuhri N. H., Guntur, Harus L. 2015. Studi Pengaruh Perubahan Tekanan Accumulator Terhadap Karakteristik Redaman dan Energi Listrik Bangkitan Pada Hydraulic Regenerative Shock Absorber (HRSA). Seminar Nasional Teknik Mesin, hal. 12-18, Surabaya. 